\title{
Strategi Kepala Madrasah dan Guru dalam Membina Akhlak Siswa MTs
}

\author{
Mohammad Jawahir ${ }^{1,2}$, Ismail Sukardi'2, Amilda² \\ ${ }_{1}$ YPP Darul Ulum Pulau Rimau, Banyuasin, Indonesia \\ ${ }^{2}$ UIN Raden Fatah, Palembang, Indonesia \\ moh.jawahir153@gmail.com
}

\begin{abstract}
This study aims to describe the strategy of the head of the madrasah in coaching students' morals and the strategy of the teachers in their guidance in MTs which includes planning, implementation and evaluation. This research is a descriptive study with a qualitative approach. The subjects of this study are the principal, teacher special class guidance, and students who are associated with this preaching class program. Data collection techniques using interviews, observation, and documentation. The data validity test used source triangulation techniques. Based on the learning management research the results of the study show that the headmaster in his strategy uses special classes, provides advice, provides habituation, exemplary, and holds student guardian meetings. Thus the monitoring of student development can be known and acted upon by the student guardian repat. As for the teacher using the way Habituation, exemplary, advice, stories of exemplary stories, and rewards (if they are good we also reply with wisdom, if we are wrong we law). Da'wah class is as a means for special students who experience problems that really need attention, parental agreement with the council of teachers, especially the head of medarasah and their cooperation is expected to realize the vision and mission of the Madrasah Tsanawiyah.
\end{abstract}

Keywords: strategy, moral development, da'wah class

\begin{abstract}
Abstrak. Penelitian ini bertujuan untuk mendeskripsikan strategi kepala madrasah dalam pembinaan akhlak siswa dan strategi guru dalam pembinaannya di MTs yang meliputi perencanaan, pelaksanaan dan evaluasi. Penelitian ini merupakan penelitian deskriptif dengan pendekatan kualitatif. Subjek penelitian ini adalah kepala sekolah, guru pembina kelas khusus, dan siswa yang terkait dengan program kelas dakwah ini. Teknik pengumpulan data menggunakan wawancara, observasi dan dokumentasi. Uji Keabsahan data menggunakan teknik triangulasi sumber. Berdasarkan penelitian manajemen pembelajaran hasil penelitian menunjukan bahwa kepala madrasah dalam strateginya menggunakan kelas khusus, memberikan nasihat-nasihat, memberikan pembiasaan-pembiasaan, keteladanan serta mengadakan rapat wali siswa. Dengan demikian pemantauan perkembangan siswa dapat diketahui dan ditindak lanjuti dari repat wali siswa tersebut. Adapun untuk guru menggunakan cara pembiasaan, keteladanan, nasihat, cerita kisah-kisah teladan, ganjaran (kalau mereka bagus kita balas juga dengan kebagusan, jika salah kita hukum). Kelas dakwah adalah sebagai sarana bagi para siswa khusus yang mengalami masalah yang sangat perlu perhatian, kesepakatan orangtua dengan para dewan guru, terutama kepala madrasah serta kerjasama mereka sangat diharapkan demi terwujudnya visi dan misi Madrasah Tsanawiyah.
\end{abstract}

Kata Kunci: strategi, pembinaan akhlak, kelas dakwah

\section{PENDAHULUAN}

Pada zaman sekarang generasi muda adalah salah satu harapan bangsa, dikarenakan ditangan seorang pemuda harapan bangsa dan dipundaknyalah masa depan bangsa. Jika seorang pemuda baik dari segi etika, moral dan 
akhlaknya, maka niscaya generasi penerus bangsa akan ikut baik, begitupun sebaliknya jika generasi muda hanya suka mabuk-mabukan, tawuran, memakai obat-obat terlarang niscaya generasi muda akan hancur seketika.

Hal ini menjadi landasan bagi semua umat terutama bagi pemuda agar kiranya memanfaatkan waktu mudanya dengan sebaik mungkin. Akan tetapi, di era modernisasi sekarang kebanyakan anak remaja atau anak muda membuang-buang waktu begitu saja mereka bebas dalam bergaul tanpa memikirkan bahaya tidaknya terhadap dirinya sendiri maupun terhadap orang lain.

Dalam lingkup sekolah, peserta didik tidak semata belajar dalam artian "penumpukan" pengetahuan dari kegiatan intruksional. Dalam proses belajar mengajar peserta didik menghadapi pula situasi-situasi yang bersangkutan dengan kehidupan pribadinya (personal) dan mereka berinteraksi pula dengan masyarakat umum (sosial). Dengan kata lain berbagai pengaruh internal dan eksternal dapat menghambat keberhasilan peserta didik. Pengaruh internal dan eksternal sangat berkaitan erat dengan lingkungan yang didiami oleh anak didik, baik dilingkungan sekolah, maupun di masyarakat (Warif, 2019).

Pendidikan merupakan bagian yang tidak terpisahkan dari hidup dan kehidupan manusia terutama pendidikan agama merupakan suatu kebutuhan, fungsi sosial, bimbingan, sarana pertumbuhan yang mempersiapkan dan membukakan serta membentuk dispilin hidup. Hal demikian membawa pengertian bahwa bagaimanapun kondisi manusia pasti akan memerlukan pendidikan.

Pendidikan agama dapat menjadi tolak ukur bagi kemajuan dan kualitas kehidupan suatu bangsa, sehingga dapat dikatakan bahwa kemajuan suatu bangsa atau negara dapat dicapai dengan salah satunya melakukan pembaharuan serta penataan pendidikan yang baik. Jadi, keberadaan pendidikan agama memiliki peranan yang sangat penting dalam menciptakan kehidupan masyarakat yang cerdas, pandai, berilmu pengetahuan yang luas, berjiwa demokratis serta berakhlakul karimah. Sedangkan pendidikan adalah usaha sadar untuk mewujudkan suasana belajar dan proses pembelajaran agar peserta didik secara efektif mengemban potensi dirinya untuk memiliki kekuatan spiritual keagamaan, pengendalian diri, kepribadian, kecerdasan, akhlak mulia, serta ketrampilan yang diperlukan dirinya, masyarakat, bangsa dan Negara (Undang-undang SISDIKNAS, 2006: 72).

Ada lima strategi dalam rangka peningkatan keimanan dan ketaqwaan peserta didik melalui pelaksanaan pendidikan karakter di sekolah, yakni: (1) 
(Strategi Kepala Madrasah dan Guru dalam Membina Akhlak Siswa di MTs)

integrasi dalam iman dan taqwa dalam visi, misi, tujuan, dan strategi sekolah, (2) optimalisasi pelaksanaan Pendidikan Agama Islam di sekolah, (3) pelaksanaan kegiatan ekstra kurikuler berwawasan iman dan taqwa, (4) pembentukan school culture yang mendukung peningkatan kualitas iman dan taqwa, dan (5) melaksanakan kerjasama antarasekolah dengan orang tua peserta didik (Wiyani, 2012: 16).

Pembentukan kepribadian yang bermoral dan berakhlak mulia tidak cukup dengan mengandalkan mata pelajaran pendidikan agama Islam yang mendapat alokasi waktu dua atau tiga jam pelajaran pada setiap minggunya (Ainiyah, 2013). Apalagi ada stigma yang berkembang bahwa keberhasilan pendidikan agama peserta didik merupakan tanggung jawab kepala madrasah dan guru agama menambah permasalahan dalam dunia pendidikan agama Islam di madrasah.

Ada beberapa ketertarikan peneliti untuk meneliti strategi kepala sekolah dalam membina akhlak siswa di MTs Al-Hikmah yaitu tanggung jawab kepala madrasah dan guru dalam membina akhlak siswa. Selain itu, perkembangan penelitian terhadap organisasi madrasah orientasinya berfokus pada pengelolaan pembelajaran sebagai satu-satunya tugas kepala madrasah dan guru sebagai pelaksana kegiatan pembelajaran untuk meningkatkan keefektifan madrasah. Namun, peneliti melihat dari sisi yang lain yakni pengaruh strategi kepala madrasah dan peran guru dilihat dari dimensi sosial budaya madrasah.

Berdasarkan studi pendahuluan yang dilakukan peneliti di MTs yang berlokasi di daerah Kertapati, sebagai lokasi penelitian merupakan salah satu lembaga pendidikan tingkat menengah yang ada di kertapati. Madrasah ini memiliki tujuan membentuk dan membina pribadi muslim menjadi orang yang paham dengan agama, berakhlak, dan sanggup mengamalkannya.

Tentunya tujuan ini didukung oleh kepala madrasah dan guru dengan menerapkan pembinaan akhlak yang baik dengan cara internalisasi nilai-nilai religius. Siswa di madrasah tersebut selalu mengawali salam dan mencium tangan guru-gurunya jika bertemu, mereka tidak berani mengawali pembicaraan jika tidak di tanya, tidak berjalan di depan guru, dan tidak berani menempati tempat duduk gurunya. Di sana juga terdapat program pembinaan akhlak yang khusus diberikan kepada siswa yang bermasalah, yaitu siswa yang memiliki latar belakang buruk pergaulan dan kebiasaan, diantaranya menjual barang-barang haram, seperti narkoba, minum-minuman keras, ikut jasa praktik merubah bentuk jasad manusia. Program tersebut diberikan awal pertama masuk di awal semester selama tiga bulan. Proram ini telah berjalan 
di semester awal pertama di tahun 2019 kemarin yang sebelumnya sudah ada kelas khusus namun seperti halnya sekolah-sekolah di lingkungan sekitarnya. Berkembang dari masalah yang berkembang dan keresahan wali santri akhirnya dibuatlah kelas dakwah ini dan ternyata berhasil memberikan dampak yang baik yang dapat di lihat secara nyata. Oleh karena itu, peneliti tertarik untuk meneliti manajemen strategi kepala madrasah dan guru dalam penerapannya, tentunya dalam memberikan pembinaan atas siswa-siswa. Tentu saja itu semua adalah tanggung jawab dari kepala madrasah, guru dan masyarakat terutama orang tua. Kepala Madrasah dan Guru sebagai seorang pendidik dalam membina akhlak siswa dengan internalisasi nilai-nilai religius yang ada di madrasah hingga dapat terbentuk karakter anak yang memiliki nilai-nilai agama. Oleh karena itu, peneliti ingin menganalisa strategi kepala madrasah dan guru dalam membina akhlak siswa di MTs.

\section{KAJIAN LITERATUR}

Di dalam strategi yang baik terdapat koordinasi tim kerja, memiliki tema, mengidentifikasi faktor pendukung yang sesuai dengan prinsip-prinsip pelaksanaan gagasan secara rasional, efisien dalam pendanaan, dan memiliki taktik untuk mencapai tujuan secara efektif.

Strategi dibedakan dengan taktik yang memiliki ruang lingkup yang lebih sempit dan waktu yang lebih singkat, walaupun pada umumnya orang sering kali mencampuradukkan ke dua kata tersebut. Strategi sering dikaitkan dengan Visi dan Misi, walaupun strategi biasanya lebih terkait dengan jangka pendek dan jangka panjang. Pada dasarnya, istilah strategi dapat dirumuskan sebagai suatu tindakan penyesuaian untuk mengadakan reaksi terhadap situasi lingkungan tertentu (baru dan khas) yang dapat dianggap penting, dimana tindakan penyesuaian tersebut dilakukan secara sadar berdasarkan pertimbangan yang wajar (Faisal, 2011: 9).

Kepala Madrasah selaku pemimpin memiliki peranan yang sangat penting dan besar dalam meningkatkan mutu guru (Buchari, 2008: 123). Oleh karena itu, seorang guru merupakan pendidik yang professional yang tidak hanya memiliki tugas mengajar, tetapi juga memiliki tugas untuk mendidik, membimbing, mengarahkan dan melatih serta menilai dan mengevaluasi hasil proses pembelajaran. Guru merupakan jabatan atau profesi yang memerlukan keahlian khusus sebagai guru. Pekerjaan ini tidak bisa dilakukan oleh orang lain yang tidak memiliki keahlian untuk melakukan kegiatan atau pekerjaan sebagai guru. Orang yang pandai berbicara dalam bidang-bidang tertentu, belum tentu dapat disebut sebagai guru yang profesional yang harus 
(Strategi Kepala Madrasah dan Guru dalam Membina Akhlak Siswa di MTs)

$\overline{\text { menguasai betul-betul seluk-beluk pendidikan dan pengajaran dengan }}$ berbagai ilmu pengetahuan yang perlu dibina dan dikembangkan melalui masa pendidikan tertentu atau pendidikan pra jabatan (Usman, 2016: 5).

Akhlak yang diajarkan guru dalam Islam bertumpu kepada fitrah yang terdapat dalam diri manusia dan kemauan yang timbul dari hati, maka pembinaan akhlak perlu dilakukan dengan beberapa langkah atau tahapan agar bisa berjalan secara efektif dan efesien, antara lain meningkatkan pengetahuan tentang akhlak Islami lewat ilmu pengetahuan. Peningkatan itu diterapkan setiap hari kepada siswa. Ini dikarenakan pengetahuan siswa akan ilmu agama masih sangat minim sekali (Basri, 2017: 654).

Sumber untuk menentukan akhlak dalam Islam, apakah termasuk akhlak yang baik atau akhlak yang tercela, sebagaimana keseluruhan ajaran Islam lainnya adalah Al-Qur'an dan Sunnah Nabi Muhammad SAW. Baik dan buruk dalam akhlak Islam ukurannya adlaah baik dan buruk menurut kedua sumber itu, bukan baik dan buruk menurut ukuran manusia. Sebab jika ukurannya adalah manusia, maka baik dan buruk itu bisa berbeda-beda. Seseorang mengatakan bahwa sesuatu itu baik, tetapi orang lain belum tentu menganggapnya baik. Begitu juga sebaliknya, seseorang menyebut sesuatu itu buruk, padahal yang lain bisa saja menyebutnya baik (Ya'qub, 2011: 35).

Dengan demikian mata pelajaran muatan lokal pada sekolah harus disesuaikan dengan kompetensi keahlian yang diselenggarakan dan diharapkan mata pelajaran muatan lokal dapat memperkaya dan meningkatkan kompetensi tamatan pada kompetensi keahlian masingmasing. Sehingga setiap lulusan mampu secara langsung terserap lapangan kerja atau paling tidak memiliki jiwa wirausaha.

\section{METODE PENELITIAN}

Dalam penelitian ini, peneliti menggunakan pendekatan penelitian kualitatif sehingga tujuan utama dari penelitian ini dapat tercapai yaitu untuk memaparkan dan menganalisis strategi kepala madrasah dan guru dalam membina akhlak siswa di MTs Palembang, bagaimana langkah-langkah serta dampaknya. Penelitian kualitatif biasanya digunakan meneliti peristiwa sosial, gejala rohani, tanda proses tanda berdasarkan pendekatan misalnya, kehidupan masyarakat, sejarah, tingkah laku fungsionalisasi organisasi, dan gerakan sosial (Ghoni \& Almanshur, 2012: 13-14). Adapun pendekatan yang digunakan pada penelitian adalah pendekatan studi kasus yaitu merupakan pengujian secara rinci terhadap, suatu latar, satu subjek, satu tempat penyimpanan, atau peristiwa tertentu. Dalam penelitian ini studi kasus dititik beratkan pada strategi kepala madrasah dan guru dalam membina akhlak 
siswa di MTs Palembang, supaya mendapatkan data deskriptif berupa katakata tertulis yang disusun berdasarkan data lisan, perbuatan, dan dokumentasi yang diamati secara holistik dan bisa diamati secara konteks. Penelitian kualitatif adalah suatu pendekatan yang juga disebut pendekatan investigasi karena biasanya peneliti mengumpulkan data dengan cara bertatap muka langsung dan berinteraksi dengan orang-orang ditempat penelitian. Peneliti melakukan beberapa kegiatan dalam pengumpulan data dengan menggunakan beberapa instrument, yaitu langsung dari informan di lapangan sesuai dengan permasalahan yang dibahas dalam penelitian ini. Teknik penggalian datanya menggunakan teknik wawancara mendalam (indepth interview) dan pengamatan (observasi partisipasi) serta didukung teknik dokumentasi sebagai teknik penunjang. Dalam penelitian ini, triangulasi digunakan dengan memeriksa derajat keabsahan data temuan dengan membandingkan antar metode yang digunakan, antar sumber data, dan antar konteks ketika data diperoleh. Hal ini dilakukan secara terus menerus selama pelaksanaan penelitian di lapangan, baik ketika akan dilaksanakan analisis data dan saat sedang melakukan analisis data itu sendiri. Dari proses ini tidak hanya keabsahan data yang diperoleh, tetapi juga data tambahan atau data yang menjelaskan secara lebih mendalam.

\section{HASIL DAN PEMBAHASAN}

1. Strategi Kepala Madrasah dalam membina akhlak siswa di MTs Palembang Setelah peneliti mengumpulkan data dari hasil observasi, wawancara dengan kepala madrasah, guru dan murid serta dokumentasi di Palembang, maka langkah selajutnya adalah melakukan analisis data dari hasil penelitian untuk menjelaskan lebih lanjut dari penelitian yang dilakukan. Berdasarkan hasil wawancara dengan Kepala Madrasah RI mengatakan hal yang melatarbelakangi adanya kelas khusus sebagai berikut: "Secara garis besar kebanyakan orang tua memasrahkan anaknya kepada kami karena mereka tidak ingin apa yang orangtua mereka lakukan yang ternyata melanggar norma-norma sosial ini bisa mengakibatkan mereka ikut terjerumus juga di dalamnya. Oleh karena itu, perlunya program khusus yang dapat memberikan benteng, binaan sehingga anak-anak yang memiliki kebiasaan diluar kebiasaan baik yang tidak ditemukan di sekolahsekolah lain ini perlu adanya penanganan khusus.

Kebanyakan anak memang dilatar belakangi ketidak tahuan akan pendidikan agama. Hal ini dikarenakan anak-anak kebanyakan dari SD, lalu ada yang putus sekolah sehingga mereka terutama yang putus sekolah 
(Strategi Kepala Madrasah dan Guru dalam Membina Akhlak Siswa di MTs)

sudah membawa kebiasaan-kebiasaan yang buruk yang mereka anggap tidak bermasalah. Dengan adanya masalah tersebut, tidak mungkin untuk penanganannya disamakan dengan sekolah lain karena masalahnya sangat kompleks. Tentunya itu semua tidak terlepas dari visi agar terwujudnya masyarakat dan bangsa yang memiliki sikap agamis, berkemampuan ilmiah, berakhlaq, dan terampil.

Hal yang melatarbelakangi masalah dalam membina akhlak siswa dengan cara diadakan pembinaan akhlak yaitu secara garis besar kebanyakan orang tua memasrahkan anaknya kepada pihak sekolah karena mereka tidak ingin apa yang orangtua mereka lakukan ternyata melanggar norma-norma sosial. Hal ini bisa mengakibatkan mereka ikut terjerumus juga di dalamnya. Oleh karena itu, perlunya program khusus yang dapat memberikan benteng, binaan sehingga anak-anak yang memiliki kebiasaan diluar kebiasaan baik yang tidak ditemukan di sekolah-sekolah lain.

Dalam pembinaan akhlak anak terutama yang memiliki karekteristik khusus perlu menggunakan media yang dapat menarik minat dan fokus kepada apa yang guru sampaikan kepada mereka. Ini juga mengantisipasi agar tidak merasa bosan. Sama seperti yang dilakukan pada pengajar MTs yang senantiasa memanfaatkan media sebagai bahan ajar dan referensi untuk semua siswa agar jangan sampai merasa bosan (Andriani, 2014: 776). Untuk penanganannya tidak mugkin sama dengan sekolah lain karena masalahnya berbeda. Namun, dengan adanya masalah tersebut kebanyakan anak memang dilatarbelakangi oleh ketidaktahuan akan pendidikan agama. Ada juga yang putus sekolah sehingga membawa kebiasaan buruk yang mereka anggap tidak bermasalah.

Berdasarkan hasil observasi yang peneliti lakukan di MTs Palembang, pembinaan akhlak yang dilakukan kepala madrasah sangatlah inten mulai dari awal siswa datang dan dilihat dari sikap dan penampilan siswa. Tentunya itu semua tidak terlepas dari visi agar terwujudnya masyarakat dan bangsa yang memiliki sikap agamis, berkemampuan ilmiah, berakhlaq, dan terampil. Berdasarkaan hasil wawancara peneliti, strategi kepala madrasah dalam membina akhlak siswa melalui pembinaan-pembinaan sebagai berikut:

a. Membuat kelas khusus

b. Memberikan nasihat-nasihat

c. Memberikan pembiasaan

d. Rapat wali siswa

Dengan demikian pembinaan akhlak yang dilakukan kepala madrasah seperti membuat kelas khusus kepada siswa yang bermasalah untuk lebih 
diberi pembinaan-pembinaan yang lebih selama 3 bulan. Setelah berjalan selama 3 bulan siswa akan dikembalikan lagi ke kelas masing-masing. Hal ini bertujuan agar siswa dapat berubah dan memiliki hati yang tenang dan tentram dalam menjalani hidup sehari-hari.

Implementasi manajemen peningkatan akhlak di sekolah perencanaannya bisa disusun dalam bentuk silabus dan program pembiasaan akhlak yang mengarah jaminan mutu sekolah, sedangkan proses pengoganisasian diterapkan berdasarkan kecakapan masingmasing dengan pelaksanaan kepala sekolah sebagai supporter menyerahkan sepenuhnya tanggung jawab kepada para guru melalui program kelas. Serta dalam pengawasannya ada lembar perkembangan siswa dan buku penghubung antara guru dan wali siswa (Nursanti, 2014: 56-59).

2. Strategi Guru dalam membina akhlak siswa di MTs AL-Hikmah Palembang.

Strategi dalam membina akhlak sangat diperlukan siswa terutama untuk kehidupannya di masyarakat. Beberapa strategi guru yang diterapkan di MTs Palembang adalah melakukan pembinaan-pembinaan sebagai berikut:

a. Pembiasaan

Pembiasaan yang diajarkan di MTs Palembang berdasarkan hasil wawancara dengan guru kelas mengatakan bahwa membiasakan anakanak menghormati guru-guru dengan mencium tangannya kalau bertemu, siswa dibiasakan datang tepat waktu. Hal ini senada dengan yang diungkapkan oleh guru BK bahwa setiap siswa yang bertemu dengan guru, siswa jabat tangan dan mencium tangannya, yang kedua dari cara berpakaian sudah diatur dalam tata tertib sekolah, tidak boleh pakai celana botol dan rok yang ketat, tidak boleh membangkang, dan bagi laki-laki tidak boleh ramput panjang.

Berdasarkan penejelasan di atas, dapat dipahami bahwa siswa dibiasakan melakukan sesuatu yang lebih baik. Menumbuhkan kebiasaan yang baik ini tidaklah mudah, akan menghabiskan waktu yang panjang. Tetapi, bila sudah menjadi kebiasaan akan sulit pula untuk berubah dari kebiasaan tersebut. Penanaman kebiasaan yang baik sangat penting dilakukan sejak awal kehidupan siswa. Agama Islam sangat mementingkan pendidikan kebiasaan. Dengan pembiasaan itulah diharapkan siswa mengamalkan ajaran agamanya secara berkelanjutan. 
(Strategi Kepala Madrasah dan Guru dalam Membina Akhlak Siswa di MTs)

b. Keteladanan

Keteladanan dilakukan dengan memberikan contoh nyata yang baik pada para siswa oleh para dewan guru dan para karyawan di sekolah. Keteladanan merupakan perilaku memberi contoh kepada orang lain dalam hal kebaikan. Beberapa contoh dari keteladanan, yakni: a) berakhlak yang baik, b) menghormati yang lebih tua, c) mengucapkan kata-kata yang baik, d) memakai busana muslim (Fitri, 2012: 110).

Berdasarkan penjelasan di atas, dapat dipahami bahwa keteladanan yang baik ialah memberikan contoh dari penampilan dan perbuatan seorang guru. Dalam pembinaan akhlak siswa seorang guru seharusnya memberikan contoh yang baik kepada siswanya sehingga strategi yang diterapkan dapat terwujud dengan baik seperti apa yang diharapkan dan seorang guru hendaknya menjaga tingkah laku serta perbuatanya karena naluri seorang siswa adalah suka meniru dari siapa yang dilihatnya.

Sifat anak-anak yang masih suka meniru terhadap orang-orang yang dikaguminya, guru yang setiap hari bertemu dengan siswa penting untuk menjadi cerminan sikap dalam melakukan tindakan. Menjadi guru yang dapat dikagumi juga bukan hal yang mudah. Harus ada pendekatan yang intensif. Oleh karenanya, keteladanan menjadi faktor utama keberhasilan dalam pembinaan (Prafitri, 2018: 352).

c. Pemberian Motivasi

Dari hasil wawancara dengan siswa kelas VII mengatakan bahwa guru sering memberi motivasi karena disetiap materi yang guru ajarkan itu selalu diselipkan dengan motivasi. Guru juga memotivasi bagaimana gambaran masa depan kita untuk kehidupan yang lebih baik dan memberikan contoh tokoh-tokoh dari luar.

Berdasarkan penjelasan di atas, dapat dipahami bahwa pemberian motivasi ialah selalu mengisahkan kisah-kisah yang membangkitkan semangat siswa. Seyogianya seorang guru ialah motivator para siswa karena dalam pembinaan akhlak siswa motivasi yang membangun semangat itu sangat penting.

d. Anjuran atau Nasihat

Anjuran/nasihat yaitu saran atau ajakan untuk berbuat atau melakukan sesuatu yang berguna. Dengan anjuran menanamkan kedisiplinan pada anak didik sehingga akhirnya akan menjalankan segala sesuatu dengan disiplin sehingga akan membentuk suatu kepribadian yang baik. Hal ini diperkuat juga dengan hasil wawancara 
siswa kelas VII mengatakan bahwa setiap hari para siswa selalu mendapatkan nasihat. Baik saat siswa ada masalah ataupun tidak. Penjelasan di atas, didukung oleh wawancara dengan guru kelas mengatakan bahwa setiap apel pagi, ada nasihat-nasihat terutama dalam pembinaan akhlak. Jadi, semua guru yang piket memberikan nasihat dalam pembinaan akhlak seperti pentingnya agama.

Berdasarkan penjelasan di atas, dapat dipahami bahwa anjuran/nasihat dalam pembinaan akhlak yang digunakan sebaiknya dilakukan dengan perkataan yang tegas dan benar yang dapat membedakan antara yang hak dengan yang batil. Ketika siswa mendapat masalah dan membutuhkan nasihat, maka nasihatilah dengan baik.

e. Hukuman dan Reword

Suatu tindakan yang mudah dijatuhkan kepada peserta didik secara sadar dan sengaja sehingga menimbulkan penyesalan. Dengan adanya penyesalan tersebut siswa akan sadar atas perbuatannya dan ia berjanji untuk tidak melakukannya dan mengulanginya.

Dari penjelasan di atas, hukuman ialah cara untuk mengarah suatu tingkah laku agar berlaku secara umum. Dalam hal ini hukuman diberikan ketika suatu tingkah laku yang tidak dilakukan oleh siswa atau siswa tidak memberikan respon atas nasihat atau teguran yang diberikan oleh pihak sekolah dalam rangka pembinaan akhlaknya.

\section{f. Pengawasan}

Suatu pengawasan bertujuan untuk mencegah dan menjaga, agar tidak terjadi sesuatu hal yang tidak diinginkan. Mengingat manusia bersifat tidak sempurna maka kemungkinan berbuat salah serta penyimpangan-penyimpangan maka sebelum kesalahan-kesalahan itu berlangsung lebih jauh, lebih baik selalu ada usaha-usaha koreksi dan pengawasan.

Berdasarkan penjelasan di atas, bahwa pengawasan yang dilakukan di sekolah tidak terlalu ketat. Padahal sebaiknya, pihak sekolah harus selalu menjaga hubungannya dengan masyarakat maupun keluarga meskipun tidak sesering mungkin dalam hal pembinaan akhlak siswa. Guru hendaknya meminta bantuan kepada orang tua karena waktu orang tua yang lebih banyak daripada guru dalam mengawasi perkembangan siswa.

Strategi adalah cara yang dilakukan oleh sebuah organisasi atau perseorangan dalam mencapai tujuan (Sagala, 2010: 128-129). Dalam 
$\overline{\text { membina akhlak, Kepala Madrasah MTs telah membuat strategi pembinaan }}$ akhlak berupa pembuatan Kelas Dakwah bagi anak-anak yang memiliki masalah serius di masyarakat hingga mereka yang harus ditanggulangi masalahnya agar tidak tertular. Adapun tujuan dari program ini adalah agar anak-anak dapat terhindar dari kebiasaan-kebiasaan yang telah dia lakukan yang sangat berbahaya bagik bagi dirinya maupun orang lain. Dalam pembentukan kelas ini kepala madrasah memanajemen dengan baik. Sebagai seorang kepala madrasah memang harus mampu memanajemen sebagai bentuk kompetensi yang harus dimilikinya, yaitu kepala madrasah sebagai seorang manajer.

Badudu mengemukakan bahwa dalam proses manajemen terlibat fungsi-fungsi pokok yang ditampilkan oleh seorang manajer/pemimpin yaitu perencanaan (Planning), pengoganisasian (Organizing), pemimpinan (leading), dan pengawasan (controling). Oleh karena itu, manajemen diartikan sebagai proses merencana, mengorganisasi, memimpin dan mengendalikan upaya organisasi dengan segala aspeknya, agar tujuan organisasi tercapai secara efektif dan efisien (Kompri, 2015: 29).

Untuk mewujudkan tujuannya tersebut, kepala madrasah menerapkan metode pembinaan akhlak dengan berbagai metode untuk diterapkan dalam strategi pembinaan di program dakwah tersebut. Yang lebih aktif dalam metode pembinaan akhlak ini adalah guru kelas dan guru BK nya. Dengan hadirnya kelas dakwah dengan manajemen yang sudah tertata serta metode yang dijalankan oleh para guru harapannya mampu membina dan mengubah akhlak siswa menjadi lebih baik. Zahruddin AR dan Hasanuddin Sinaga dalam Zubaedi mengemukakan bahwa definisi akhlak dalam pengertian sehari-hari disamakan dengan "budi pekerti", kesusilaan, sopan santun, tata kerama (versi bahasa Indonesia) sedang dalam bahasa Inggrisnya disamakan dengan istilah molal atau ethic (Zubaedi, 2013: 66).

Faktor yang mempengaruhi pembentukan akhlak merupakan faktor penting yang berperan dalam menentukan baik dan buruknya tingkah laku seseorang. Adapaun faktor-faktor yang mempengaruhi pembentukan akhlak, meliputi naluri, keturunan, lingkungan, kebiasaan, kehendak dan pendidikan.

1. Strategi Kelas Dakwah

a. Pembiasaan

Beberapa cara membina akhlak adalah dengan cara pembiasaan, dimana syarat yang harus dipenuhi adalah 1). segera dimulai sebelum terlambat, 2). dilakukan secara terus menerus, teratur dan terprogram sehingga pada akhirnya akan terbentuk sebuah kebiasaan yang utuh, permanen dan konsisten, 3) pembiasaan hendaknya diawasi secara 
ketat, konsisten dan tegas, jangan memberi kesempatan yang luas kepada warga sekolah untuk melanggar kebiasaan yang telah ditanamkan 4) pembiasaan yang ada pada mulanya hanya bersifat mekanistis, hendaknya secara berangsur-angsur diubah menjadi kebiasaan yang tidak verbalistik dan menjadi kebiasaan yang disertai dengan kata hati warga sekolah itu sendiri (Arief, 2002:110).

Dalam pembinaan akhlak, kepala madrasah beserta para guru termasuk guru BK menerapkan metode membina dengan cara membiasakan dalam beribadah seperti sholat, mengikuti dan mendengarkan ceramah-ceramah, sholat dzuhur berjama'ah, bersalaman kepada bapak dan ibu guru serta mengucapkan salam jika bertemu. Selain itu juga menerapkan keteladanan.

Dengan demikian, sikap guru dan kepala madrasah dengan keyakinan jika dalam kurun waktu lebih dari 40 hari, maka anak-anak akan terbiasa sehingga akhlak yang ditanamkan oleh para guru nantinya masih dapat terjaga meski tanpa pengawasan. Jadi, para guru dan kepala madrasah telah menerapkan konsep pembiasaannya sesuai dengan teori yang ada. Apalagi program ini dibuat khusus selama 3 bulan.

b. Keteladanan

Model keteladanan sebagai pendekatan digunakan untuk merealisasikan tujuan pendidikan dengan memberi contoh keteladanan yang baik bagi siswa atau warga sekolah agar mereka dapat berkembang dengan baik, baik secara fisik maupun mental dan memiliki akhlak yang baik. Keteladanan memberikan kontribusi yang sangat besar dalam pendidikan ibadah, akhlak, dan lain sebagianya.

Guru mengajarkan agar mereka bersalaman dengan orang yang lebih tua dari mereka dan mengucapkan salam saat bertemu. Sebelum anak-anak melakukan itu semua, mereka para guru mencontohkan kepada para siswa yang lain. Guru memberikan contoh untuk saling bersalaman dan ikut sholat berjama'ah. Saling memberi salam dan bertegur sapa. Agar tidak rikuh para guru pun sering memberikan keteladanan dengan menyapa anak-anak dan memberi salam kepada mereka. Namun, bedanya saat bersalaman mereka mencium tangan guru-gurunya. Inilah keteladanan yang diberikan para guru kepada mereka.

Dengan keteladanan seperti ini, kelebihannya memudahkan dalam menerapkan apa yang telah diajarkan oleh guru. Mengaplikasikan apa yang telah diajarkan, mudah dalam mengevaluasinya karena semua 
(Strategi Kepala Madrasah dan Guru dalam Membina Akhlak Siswa di MTs)

berwujud sikap secara nyata dan langsung dapat dilihat. Selain tujuan telah berhasil atau belum dapat dilihat dan tercipta hubungan yang harmonis antara siswa dengan guru dan warga sekolah.

c. Kemitraan

Strategi kemitraan atau kerjasama antara orangtua atau lingkungan sekitar terhadap pengalaman agama perlu ditingkatkan sehingga memberikan motivasi serta ikut berpartisipasi dalam program kelas dakwah ini. Tidak mungkin program ini dapat berhasil jika tanpa adanya dukungan dari pihak keluarga siswa. Hubungan kemitraan yang baik harusnya tetap dipelihara agar terwujud 1) saling pengertian 2) saling menerima, untuk tidak saling berjalan menurut kemauannya sendiri-sendiri 3) adanya saling percaya, tidak saling mencurigai, 4) saling menghargai, untuk tidak saling mengklaim kebenaran, 5) kasih sayang untuk tidak saling membenci dan iri hati (Muhaimin, 1999: 22).

Dalam pembinaan akhlak perlu juga adanya kerjasama antara sekolah dengan pihak keluarga. Hal ini dikarenakan oleh faktor keluarga yang sering bertengkar dengan orang tua yang menjadi pengaruh akan adanya keberhasilan pembinaan di madrasah. Anak bisa sering berkelahi dan membantah kepada guru dan teman (Juraini, 2018: 42).

Hubungan mitra madrasah dengan guru yang terjadi terjalin dengan baik, ini bisa dilihat dengan adanya indikator keberhasilan akhlak anak terhadap orangtua. Terhadap orangtua anak-anak sudah mulai sopan. Atas apa yang diberitakan orangtua terhadap anaknya secara berangsur-angsur setiap minggunya untuk dievaluasi apa saja kendalanya yang dihadapi yang kemudian ditindaklanjuti oleh pihak madrasah, sehingga untuk perkembangan selanjutnya dipantau sebulan sekali. Orangtua sangat mendukung program ini, antusias dan dukungan agar anaknya menjadi lebih baik terlihat dari dukungan mereka saat rapat wali siswa.

Beberapa tujuan pembinaan akhlak adalah meliputi: 1) supaya dapat terbiasa melakukan yang baik, indah, mulai, terpuji, serta menghindari yang buruk, jelek, hina dan tercela 2) supaya hubungan kita dengan Allah SWT dan dengan sesama makhluk selalu terpelihara dengan baik dan harmonis (Umary, 1998: 136).

Kepala madrasah pada saat kami ajak wawancara mengemukakan tujuan dari pembinaan akhlak ini adalah anak dapat menghilangkan kebiasaan buruknya dan paling tidak dapat menguranginya hingga berangsur-angsur hilang. Selain itu dalam bidang akademik dapat meningkat. Dapat peneliti simpulkan jika demikian tujuan yang telah 
diidam-idamkan oleh madrasah sudah dapat tercapai, meski tidak secara keseluruhan anak semua bisa mencapainya secara sempurna. Namun, bagi mereka yang sudah ada perubahan dan kita masukkan di kelas untuk belajar masih dapat pemantauan secara terus menerus.

Berdasarkan strategi perlakuan yang diberikan oleh kepala madrasah beserta guru yang mengampu bidang baik akhlak, syaria'at, alQur'an selama tiga bulan, telah meperlihatkan hasil. Hal itu dapat dilihat dari hasil pengamatan yang peneliti lakukan sendiri dibantu dengan guru dalam memperoleh data dari awal hingga akhir selama proses pembinaan pada kelas dakwah seperti pada Tabel 1.

Tabel 1. Perkembangan Siswa dengan Karakteristik Khusus

\begin{tabular}{|c|c|c|}
\hline Masalah & Sebab & $\begin{array}{c}\text { Perkembangan setelah } \\
\text { ikut kelas }\end{array}$ \\
\hline Kurir obat terlarang & Ekonomi & $\begin{array}{l}\text { Tidak lagi jadi kurir, rajin ke } \\
\text { masjid, rajin sekolah }\end{array}$ \\
\hline Kurir obat terlarang & Ekonomi & $\begin{array}{l}\text { Tidak lagi jadi kurir, tapi } \\
\text { sering lihat rekan yang } \\
\text { kurir }\end{array}$ \\
\hline Penghisap lem ibon & Ikut teman & Penghisap lem ibon \\
\hline $\begin{array}{l}\text { Orang tua pengedar } \\
\text { obat terlarang, orang } \\
\text { tua takut ikut anaknya } \\
\text { terjerumus }\end{array}$ & $\begin{array}{l}\text { Agama anak } \\
\text { kurang, kurang } \\
\text { bekal atas } \\
\text { bahayanya, sabu }\end{array}$ & $\begin{array}{l}\text { Rajin sholat terutama } \\
\text { jama'ah }\end{array}$ \\
\hline Peminum alkohol & Diajak teman & $\begin{array}{l}\text { Tidak lagi minum alkohol, } \\
\text { sering sholat }\end{array}$ \\
\hline Penghisap lem ibon & Ingin coba-coba & $\begin{array}{l}\text { Tidak lagi menghisap lem } \\
\text { ibon, sering sholat dan baca } \\
\text { Al-qur'an habis maghrib }\end{array}$ \\
\hline Penghisap lem ibon & Ikut teman & $\begin{array}{l}\text { Tidak lagi menghisap lem } \\
\text { ibon, bantu orang tua }\end{array}$ \\
\hline Peminum alkohol & Lingkungan sekitar & $\begin{array}{l}\text { Tidak Lagi minum alkohol, } \\
\text { lebih sering di rumah }\end{array}$ \\
\hline Penghisap lem ibon & $\begin{array}{l}\text { Kurang percaya } \\
\text { diri jika tidak } \\
\text { memakai sabu }\end{array}$ & $\begin{array}{l}\text { Masih menghisap lem ibon, } \\
\text { tapi tidak sesering dulu dan } \\
\text { sekarang hampir tidak lagi }\end{array}$ \\
\hline Kurir obat terlarang & Ekonomi & $\begin{array}{l}\text { Tidak lagi ikut jualan di } \\
\text { rumah dengan ibu }\end{array}$ \\
\hline
\end{tabular}


(Strategi Kepala Madrasah dan Guru dalam Membina Akhlak Siswa di MTs)

\begin{tabular}{|c|c|c|}
\hline Peminum alkohol & Lingkungan sekitar & $\begin{array}{l}\text { Tidak lagi meminum } \\
\text { alcohol, lebih sering di } \\
\text { rumah }\end{array}$ \\
\hline $\begin{array}{l}\text { Ortu pengedar obat } \\
\text { terlarang, takut ikut } \\
\text { terjerumus }\end{array}$ & $\begin{array}{l}\text { Orang tua ingin } \\
\text { anaknya tidak ikut- } \\
\text { ikutan }\end{array}$ & $\begin{array}{l}\text { Sering sholat dan wirid } \\
\text { sehabis sholat dan baca } \\
\text { qur'an sehabis dzuhur dan } \\
\text { maghrib }\end{array}$ \\
\hline Kurir obat terlarang & Ekonomi & $\begin{array}{l}\text { Tidak lagi menjadi kurir } \\
\text { obat terlarang, lebih sering } \\
\text { di rumah bantu orangtua } \\
\text { jual yang makanan halal }\end{array}$ \\
\hline Tanam alis mata & $\begin{array}{l}\text { Ingin dapat uang } \\
\text { lebih }\end{array}$ & $\begin{array}{l}\text { Tidak lagi menanam alis, } \\
\text { ikut jualan warung yang } \\
\text { halal saja }\end{array}$ \\
\hline Kurir obat terlarang & Ekonomi & $\begin{array}{l}\text { Tidak lagi menjadi kurir } \\
\text { obat terlarang, jualan kue }\end{array}$ \\
\hline Kurir obat terlarang & Ekonomi & $\begin{array}{l}\text { Tidak lagi menjadi kurir } \\
\text { obat terlarang }\end{array}$ \\
\hline Tukang suntik pelacur & $\begin{array}{l}\text { Ingin dapat uang } \\
\text { lebih }\end{array}$ & $\begin{array}{l}\text { Tidak ikut lagi tukang } \\
\text { suntik pelacur, lebih sering } \\
\text { di rumah }\end{array}$ \\
\hline Tanam alis mata & $\begin{array}{l}\text { Ingin dapat uang } \\
\text { lebih }\end{array}$ & $\begin{array}{l}\text { Tidak lagi menanam alis } \\
\text { mata, sibuk hafalan }\end{array}$ \\
\hline Peminum alkohol & Keluarga & $\begin{array}{l}\text { Tidak lagi, sibuk dengan } \\
\text { hafalan }\end{array}$ \\
\hline Tukang suntik pelacur & $\begin{array}{l}\text { Ingin dapat uang } \\
\text { lebih }\end{array}$ & $\begin{array}{l}\text { Masih ikut tukang suntik, } \\
\text { tapi tidak bekerja untuk } \\
\text { nyuntik }\end{array}$ \\
\hline
\end{tabular}

Selain bekerja sama dengan guru, peneliti juga mencaritahu lewat kesehariannya, apakah benar intensitas kebiasaan yang mereka ubah dari sebelum perlakuan hingga akhir perlakuan memang nyata atau dibuat-buat.

\section{KESIMPULAN}

Strategi kepala madrasah dalam membina akhlak siswa adalah dengan cara membuat kelas khusus untuk siswa yang bermasalah selama 3 bulan. Kemudian dengan melakukan pembinaan-pembinaan seperti memberikan nasihat-nasihat, melakukan pembiasaan seperti membaca do'a, yasin dan zikir bersama di pagi hari, serta mengadakan rapat dengan orangtua siswa. 
Sedangkan, strategi guru dalam membina akhlak siswa adalah dengan melakukan pembinaan-pembinaan seperti pembiasaan, keteladanan, anjuran atau nasihat, hukuman dan reword, dan pengawasan. Dengan demikian, pengembangan akhlak siswa dapat diterapkan sesuai dengan tujuan dan visi sekolah.

\section{DAFTAR PUSTAKA}

Ainiyah, N. (2013). Pembentukan Karakter Melalui Pendidikan Agama Islam. Jurnal Al-Ulum, 13 (1), 25-38.

Andriani, R. (2014). Pelaksanaan Pembinaan Akhlak Dalam Pembelajaran Bagi Siswa Tunagrahita. JUPPEKhu, 3 (3).

Arief, A. (2002). Pengantar Ilmu dan Metodologi Pendidikan Islam. Jakarta: Ciputra Pers.

Basri, H., \& Daulay, H. P. (2017). Pembinaan Akhlak dalam Menghadapi Kenakalan Siswa di Madrasah Tsanawiyah Bukhari Muslim Yayasan Taman Perguruan Islam (YTPI) Kecamatan Medan Baru Kota Medan. EDU RILIGIA, 1 (4).

Buchari, A. (2008). Guru Profesional Menguasai Metode dan Terampil Mengajar. Bandung: Alfabeta.

Faisal, A. (2011). Strategi Pemasaran. Bandung: Angkasa.

Fitri, A. Z. (2012). Pendidikan Karakter Berbasis Niai dan Etika di Sekolah. Jakarta: Ar-Ruzz.

Ghoni, M. D \& Almanshur, F. (2012). Metodologi Penelitian Kualitatif. Malang: Ar-ruz Media.

Juraini, F., Habibah, S., \& Mislinawati, M. (2018). Pembinaan Akhlak Terhadap Siswa dalam Proses Pembelajaran di SD Negeri Unggul Lampeneurut Aceh Besar. JIM Unsyiah, 3 (2).

Kompri. (2015). Manajemen Sekolah Orientasi Kemandirian Kepala Sekolah. Pustaka Pelajar: Yogyakarta.

Muhaimin. (1999). Arah Baru Pengembangan Pendidikaan Islam. Bandung: Rosdakarya.

Nursanti, R. (2014). Manajemen Peningkatan Akhlak Mulia di Sekolah Berbasis Islam. Jurnal Kependidikan, II (2).

Prafitri, B \& Subekti, (2018). Metode Pembinaan Akhlak dalam Peningkatan Pengamalan Ibadah Peserta Didik di SMP N 4 Sekampung Lampung Timur. FITRAH Jurnal Kajian Ilmu-ilmu Keislaman, 4 (2).

Sagala, S. (2010). Manajemen Strategik dalam Peningkatan Mutu Pendidikan. Bandung: Alfabeta. 
(Strategi Kepala Madrasah dan Guru dalam Membina Akhlak Siswa di MTs)

Umary, B. (1998). Materi Akhlak. Solo: Ramadhani.

Undang-undang SISDIKNAS. (2006). Sistem Pendidikan Nasional No 20 Tahun 2003. Bandung: Citra Umbara.

Usman, U. (2016). Menjadi Guru Profesional. Bandung: PT Remaja Rosdakarya.

Warif, M. (2019). Strategi Guru Kelas dalam Menghadapi Peserta Didik yang Malas Belajar. Tarbawi, 4 (1), 38-55.

Wiyani, N. A. (2012). Pendidikan Karakter Berbasis Iman dan Taqwa. Sleman: Teras.

Ya'qub, H. (2011). Etika Islam: Pembinaan Akhlaqul Karimah (Suatu Pengantar). Bandung: CV. Diponegoro.

Zubaedi. (2013). Desain Pendidikan Karakter: Kompetensi dan Aplikasinya Dalam Lembaga pendidikan. Jakarta: Prenada Media Group. 
